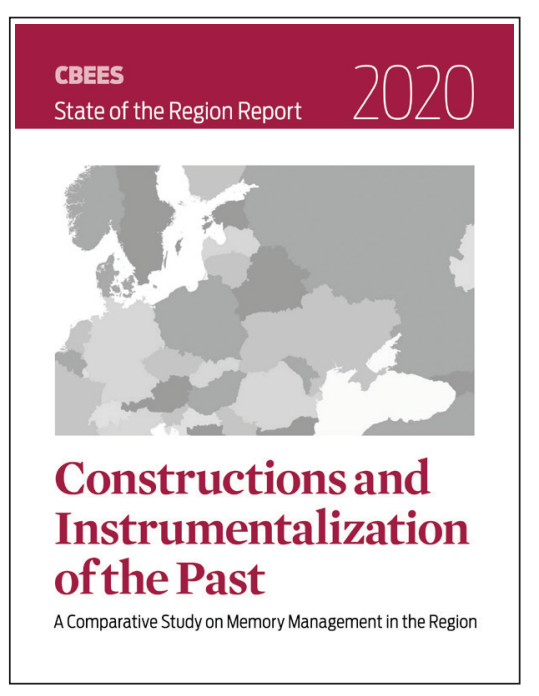

\title{
Constructions and Instrumentalization of the Past: A Comparative Study of Memory Management in the Region
}

\author{
Ninna Mörner (red.) \\ Stockholm: CBEES 2020 \\ 186 sider. ISBN 9789185139125
}

Anmeldt af Rasmus Nilsson [lektor University College London, r.nilsson@ucl.ac.uk]

\begin{abstract}
Dette værk, der fokuserer på den politiske brug af historie og erindring, er udgivet af Centre for Baltic and East European Studies (CBEES), der hører under Södertörns Högskola i Stockholm, og er planlagt til at være den første udgivelse i en serie af årlige rapporter, der undersøger og sammenligner sociopolitiske udviklinger og institutioner i Østeuropa. I denne, første rapport har CBEES samlet en lang række forskere fra fremtrædende universiteter (Det bør nævnes, at disse universiteter indbefatter University College London, hvor denne anmelder arbejder.). Når man tager disse forskeres hidtidige værker i betragtning, er det ikke overraskende, at denne rapport er af høj kvalitet og i alle kapitler bærer præg af, at forfatterne har indgående kendskab til deres studerede område. Fra denne anmelders synspunkt giver områdestudier ofte de mest interessante resultater, og det er derfor betryggende, at CBEES her har valgt forfattere, der ikke prøver at placere den studerede region "imellem Øst og Vest«, for eksempel, men i stedet er interesserede i regionen i sig selv. Det kan dog betvivles, om rapporten fuldt ud har held med at placere de inkluderede lande i én, sammenlignelig region.
\end{abstract}

Før anmeldelsen tager fat i det spørgsmål, er det dog værd at fokusere på alle de dele af rapporten, der bestemt gør den værd at læse. Først og fremmest er der valget af rapportens tema: den politiske brug af historie og erindringer i Østeuropa. Det tema har i stigende grad været i fokus de seneste årtier, efterhånden som regionen bevægede sig væk fra den kommunistiske fortid og prøvede at finde sig til rette i det nye Europa og, for mange landes vedkommende, i den nye Europæiske Union. Nogle af de mest fremtrædende og indflydelsesrige akademiske artikler og bøger udkom i forbindelse med 20- og 30-årsjubilæerne efter kommunismens fald i 
Østeuropa, men der er selvsagt stadig løbende behov for sådanne udgivelser - ikke mindst når man, som mange forfattere i denne rapport, antager, at historie og erindringer benyttes af ledere (eller ledere in spe) til at sikre deres magt. Og forfattere såsom Muriel Blaive (der skriver om Tjekkiet) skal bestemt have ros for at påpege, at det ikke kun er (semi-)autokratiske ledere, der søger politisk gavn af at udvælge de særlige facetter af fortiden, der placerer nuværende styrer i et godt lys.

Læseren får godt overblik over, hvor vidtstrakt den politiske brug af historie og erindringer er i Østeuropa, fordi rapporten gør en dyd ud af at analysere en lang række lande i regionen. Efter indledningen dækker den første del af rapporten nogle af regionens lande i mere eller mindre internationale essays, før den anden del af rapporten så studerer situationen i enkelte lande nærmere, kapitel efter kapitel - fra Litauen i nord og Tyskland i vest til Tyrkiet i syd. Samtidig sørger forfatterne for, at læseren introduceres til den politiske brug af historie og erindring fra mange forskellige vinkler, herunder den populær-kulturelle (såsom i Irina Sandomirskajas indledende, postsovjetiske kapitel), den statsakademiske (såsom i Joanna Michlics kapitel om Polen) og den uddannelsesmæssige (såsom i Evelina Kelbechevas kapitel om Bulgarien). Det er dog lidt en skam, at rapporten ikke har afsat et kapitel til specifikt at engagere sig i den politiske brug af historie i Rusland. Javel, den russiske situation nævnes bestemt i de indledende kapitler, og Rusland dukker gentagne gange op i løbet af hele rapporten, men aldrig i en specielt systematisk form. Det er ikke nødvendigvis et problem i sig selv (på trods af denne anmelders præferencer), men det illustrerer en mere grundlæggende udfordring, som rapporten aldrig løser.

Tag endelig ikke fejl. Dette er et glimrende, opdateret og alsidigt værk, der bør læses af alle, som er interesserede i den politiske brug af historie og erindring generelt og i de her omtalte lande. Men rapporten bliver aldrig for alvor sammenlignende på tværs af de forskellige kapitler. Der er forsøg på, såvel først som sidst i rapporten, at fremhæve emner og analytiske forståelsesrammer, der rækker på tværs af de her indbefattede landestudier. Og det er glimrende forsøg af nogle af de mest rutinerede forskere, såsom Barbara Törnquist-Plewa, der for eksempel henviser til Østeuropas dobbelte totalitære arv fra kommunismen og nazismen. Det er for så vidt ganske brugbart. Men hvis en af hovedpointerne i rapporten er, at historie og erindring altid skal ses som en del af politisk magtbrug (bredt forstået), så er vi også nødt til at erkende, at hele den politiske magtbrug af diskussionen om socialisme i forhold til fascisme for eksempel ikke længere bare finder sted i de her beskrevne lande, men også for eksempel i store dele afVesteuropa og Nordamerika. Rapporten kunne måske stadig have påvist, hvordan dette og andre emner alligevel kommer til udtryk på en for rapportens region helt særegen måde, men det havde nok krævet kapitler hele vejen igennem rapporten, der sammenlignede emner indenfor den politiske brug af historie og erindring på tværs af lande og ikke land efter land. Og det er ikke, hvad hoveddelen af denne rapport tilbyder.

$\mathrm{Nu}$ virker det, som om denne anmelder ikke kan lide landekapitlerne. Det er ikke tilfældet. De er alle sammen dejligt analyserende, velskrevne og brugbare - og 
ofte fint i stand til at vise en flertydig udvikling gennem årene i deres lande, som for eksempel i Violeta Davioliūtès kapitel om Litauen og minderne efter Anden Verdenskrig eller i Talin Suciyans analyse af tyrkiske organisationers forhold til det armenske folkemord. Problemet er ikke kapitlernes eller rapportens, men områdestudiernes som sådant. Hvad er det, der gør de baltiske lande og Østeuropa til én region? Hvorfor skal vi i dag, næsten 30 år efter Sovjetunionens fald, stadig se dem som havende noget til fælles? Måske fordi aktører i og uden for landene her stadig behandler landene som havende noget til fælles? Hvis det er tilfældet, er der brug for mere sammenlignende og internationale vinkler, end det meste af denne rapport giver os. Og det er så her, hvor denne anmelder igen tænker, at en lidt mere systematisk, katalyserende brug af den russiske vinkel måske havde hjulpet. 